Aline Rimoldi Ribeiro'

Vagner José Mendonça"

Renata Tomé Alves"II

Isabel Martinez"

Renato Freitas de Araújo ${ }^{\text {IV }}$

Fernanda Mello ${ }^{v}$

João Aristeu da Rosa"

Departamento de Parasitologia. Instituto de Biologia. Universidade Estadual de Campinas. Campinas, SP, Brasil

Departamento de Ciências Biológicas Faculdade de Ciências Farmacêuticas. Universidade Estadual Júlio de Mesquita Filho. Araraquara, SP, Brasil

III Departamento de Análises Clínicas Toxicológicas e Bromatológicas. Faculdade de Ciências Farmacêuticas. Universidade de São Paulo. Ribeirão Preto, SP, Brasil

Secretaria Estadual de Saúde da Bahia. Salvador, BA, Brasil

Secretaria de Saúde do Estado do Rio Grande do Sul. Porto Alegre, RS, Brasil

Correspondência | Correspondence: João Aristeu da Rosa

Faculdade de Ciências Farmacêuticas Campus de Araraquara

Rodovia Araraquara-Jaú Km 1

14801-902 Araraquara, SP, Brasil

E-mail: rosaja@fcfar.unesp.br

Received: $1 / 28 / 2013$

Approved: 11/7/2013

Article available from: www.scielo.br/rsp

\section{Trypanosoma cruzi strains from triatomine collected in Bahia and Rio Grande do Sul, Brazil}

\author{
Trypanosoma cruzi isolado de \\ triatomíneos coletados na Bahia e \\ Rio Grande do Sul
}

\begin{abstract}
OBJECTIVE: Collection of triatomines in domestic, peridomestic and sylvatic environments in states of Bahia and Rio Grande do Sul, Northeastern and Southern Brazil respectively, and isolation of Trypanosoma cruzi strains.
\end{abstract}

METHODS: First, the captured triatomines were identified using insect identification keys, then their intestinal content was examined by abdominal compression, and the samples containing trypanosomatid forms were inoculated in LIT medium and Swiss mice.

RESULTS: Six triatomine species were collected in cities in Bahia, namely Panstrongylus geniculatus (01), Triatoma melanocephala (11), T. lenti (94), T. pseudomaculata (02), T. sherlocki (26) and T. sordida (460), and two in cities in Rio Grande do Sul, namely T. circummaculata (11) and $T$. rubrovaria (115). Out of the specimens examined, T. cruzi was isolated from 28 triatomine divided into four different species: T. melanocephala (one), T. lenti (one), T. rubrovaria (16) and T. sordida (10). Their index of natural infection by $T$. cruzi was $6.4 \%$.

CONCLUSIONS: The isolation of $T$. cruzi strains from triatomines found in domestic and peridomestic areas shows the potential risk of transmission of Chagas disease in the studied cities. The maintenance of those T. cruzi strains in laboratory is intended to promote studies that facilitate the understanding of the parasite-vector-host relationship.

DESCRIPTORS: Chagas Disease, transmission. Triatominae, Trypanosoma cruzi, isolation. Communicable Diseases, epidemiology. 


\section{RESUMO}

OBJETIVO: Isolar cepas de Trypanosoma cruzi em triatomíneos capturados nos ambientes domiciliar, peridomiciliar e silvestre da Bahia e do Rio Grande do Sul.

MÉTODOS: Os triatomíneos capturados nos estados da Bahia e Rio Grande do Sul foram identificados por meio de chaves entomológicas. O conteúdo intestinal foi examinado por compressão abdominal e as amostras que continham formas de Trypanosomatidae foram inoculadas em meio de cultura Liver Infusion Tryptose e em camundongos Swiss.

RESULTADOS: Foram identificadas seis espécies de triatomíneos nas coletas realizadas em municípios do Estado da Bahia: Panstrongylus geniculatus (01), Triatoma melanocephala (11), T. lenti (94), T. pseudomaculata (02), T. sherlocki (26) e T. sordida (460), e duas no Estado do Rio Grande do Sul: $T$. circummaculata (11) e T. rubrovaria (115). Dos exemplares examinados, T. cruzi foi isolado de 28 triatomíneos pertencentes a quatro espécies: T. melanocephala (uma), T. lenti (uma), T. rubrovaria (16) e T. sordida (10). O índice de infecção natural de triatomíneos por $T$. cruzi foi de $6,4 \%$.

CONCLUSÕES: O isolamento de cepas de T. cruzi em triatomíneos encontrados no intra e peridomicílio reflete o potencial risco de transmissão da doença de Chagas nos municípios estudados.

DESCRITORES: Doença de Chagas, transmissão. Triatominae, Trypanosoma cruzi, isolamento. Doenças Transmissíveis, epidemiologia.

\section{INTRODUCTION}

Chagas disease is estimated to affect around 10 million people worldwide and 25 million people in Latin America are at risk of infection. ${ }^{7}$

In relation to the epidemiology of Chagas disease in Brazil, in 1996 the Chagas Disease Control Program, of the National Foundation for Health/Brazilian Ministry of Health (FNS/MS), collected 290,576 triatomines, of which 201,156 (69.2\%) were captured in the Northeast region, where more attention and care are required in view of the presence of sylvatic species that are potentially invasive and difficult to control. ${ }^{8}$

In 1975, the Superintendency for Public Health Campaigns (SUCAM) implemented the Chagas Disease Control Program in the state of Rio Grande do Sul, Southern Brazil. This program was responsible for methodological standardization, supply regulation and rationalization of the activities that provided a basis for vector control. ${ }^{4}$ Almeida et al ${ }^{1}$ (2009) reported the presence of Triatoma rubrovaria naturally infected by T. cruzi in domestic and peridomestic areas of Rio Grande do Sul, where Rosa et $\mathrm{al}^{18}$ (2000) collected both T. rubrovaria and Triatoma circummaculata also naturally infected by the parasite. Pena et $\mathrm{al}^{16}(2011)$ isolated $T$. cruzi strains that came from patients, reservoirs and vectors during an outbreak of acute Chagas disease in the city of Navegantes, state of
Santa Catarina, Southern Brazil, which shows the persistence of transmission of the disease in that region.

Silveira \& Pinto $\operatorname{Dias}^{20}(2011)$ reported the control activities exercised on a regular basis in Brazil, using systematic methodology and epidemiological, entomological and serological surveys. These actions led to depletion of the main vector species, Triatoma infestans, allochthonous and domestic only, and control of household colonization species that are important in transmission. Transmission is now residual in native species such as Triatoma brasiliensis and Triatoma pseudomaculata. There is a risk of domestication of species, previously considered of wild behavior, such as Panstrongylus lutzi and T. rubrovaria, beyond the possibility of human infections, directly related to the zoonotic transmission cycle. Therefore, it is still essential to maintain strict entomological surveillance. ${ }^{20}$

The ecological history of the distribution of the several strains of $T$. cruzi is marked by important changes starting from the migration of mammals in the Americas, habitat expansion, and destruction and urbanization of the environment by humans. ${ }^{22}$

Collecting species, studying geographic distribution and infection of triatomines by $T$. cruzi can contribute to the reporting of bugs and surveillance measures. 
This study aimed to isolate Trypanosoma cruzi strains from triatomines in domestic, peridomestic and sylvatic environments in states of Bahia and Rio Grande do Sul, Brazil.

\section{METHODS}

In Rio Grande do Sul, triatomines were collected in sylvatic environments in fourteen sites in six cities (Figure) in the period between 2002 and 2003. In the state of Bahia, triatomines were captured in sylvatic, peridomestic and domestic areas in nine sites of five cities in 2003, 2006, 2008 and 2009 (Table 1). The Bahia and Rio Grande do Sul State Departments of Health cooperated in the collection activities. The cities were chosen according to the report against triatomine by the health departments of Bahia and Rio Grande do Sul.

Environments of domestic units closed by doors, i.e., houses and annexes, were considered domestic ecotopes.
Triatomines were found sheltering in cracks in those environments, under beds or behind objects placed along the walls. The studied peridomestic ecotopes were in a radius of $50 \mathrm{~m}$ from the houses, where domestic animals sleep or are bred. In the active researches, triatomines were collected manually with tweezers and placed in individual flasks labeled with information on the place of collection. ${ }^{12}$

The captured triatomines were taken to the Triatominae Insectarium of the Faculdade de Ciências Farmacêuticas of the Universidade Estadual Paulista "Júlio de Mesquista Filho” (FCF/UNESP) at Araraquara, SP, Southeastern Brazil, where they were identified according to morphological characters present in insect identification keys ${ }^{13}$ and kept under controlled temperature and humidity $\left(27 \pm 2^{\circ} \mathrm{C}\right.$ and $\left.60 \pm 3 \% \mathrm{RH}\right)$. This species are maintained in the colony with controlled conditions in the Laboratory of Parasitology. The capture was conducted by a group containing guides, researchers, and department of health employees and lasted

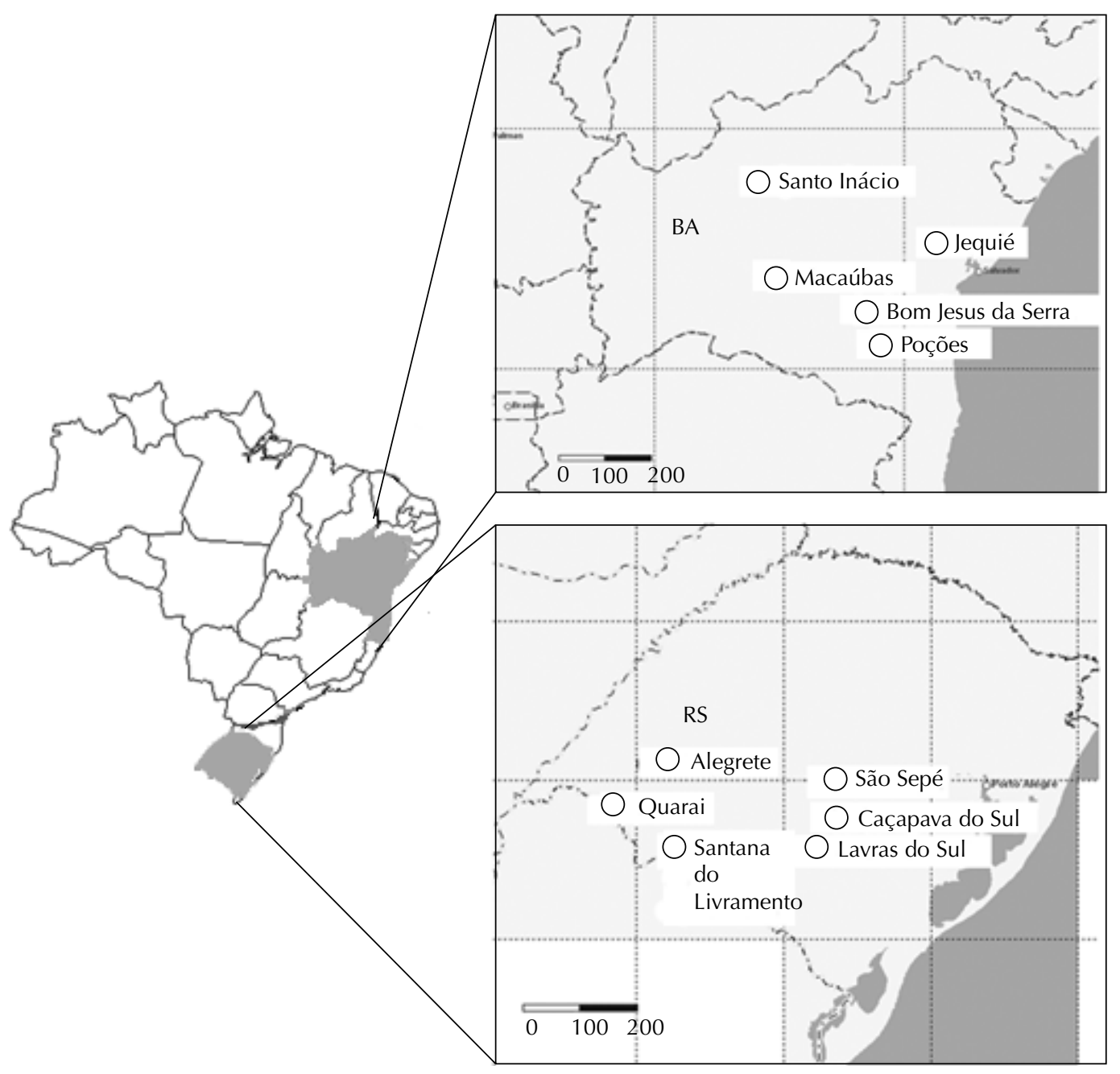

Figure. Cities in Bahia and Rio Grande do Sul where triatomines were collected, 2002-2009. 
Table 1. Locality, collected species, year and environment of collection. Brazil, 2002-2009.

\begin{tabular}{|c|c|c|c|c|}
\hline State & Locality & Triatominae & Year & Ecotope \\
\hline \multirow{6}{*}{$\begin{array}{l}\text { Rio Grande } \\
\text { do Sul }\end{array}$} & Sao Sepé & T. rubrovaria & 2002 & $S$ \\
\hline & Caçapava do Sul & T. rubrovaria/T. circummaculata & 2002 & S \\
\hline & Lavras & T. rubrovaria/T. circummaculata & 2002 & $S$ \\
\hline & Alegrete & T. rubrovaria & 2002 & $\mathrm{~S}$ \\
\hline & Quaraí & T. rubrovaria & 2002 & $\mathrm{~S}$ \\
\hline & Sta. Livramento & T. rubrovaria & 2003 & $S$ \\
\hline \multirow[t]{5}{*}{ Bahia } & Santo Inácio & T. sordida/T. sherlocki & 2003 & $\mathrm{P} / \mathrm{S}$ \\
\hline & Santo Inácio & $\begin{array}{l}\text { T. sordida/T. sherlocki/ } \\
\text { T. pseudomaculata }\end{array}$ & 2006 & $\mathrm{P} / \mathrm{D}$ \\
\hline & Macaúbas & T. lenti/T. sordida/T. pseudomaculata & 2008 & $\mathrm{P} / \mathrm{D}$ \\
\hline & Macaúbas & $\begin{array}{l}\text { T. lenti/T. sordida/T. pseudomaculata/P. } \\
\text { geniculatus }\end{array}$ & 2009 & $\mathrm{P} / \mathrm{D}$ \\
\hline & $\begin{array}{c}\text { Poções/Jequié/Bom Jesus } \\
\text { da Serra }\end{array}$ & T. melanocephala & 2009 & $\mathrm{P}$ \\
\hline
\end{tabular}

S: Sylvatic; P: Peridomestic; D: Domestic

around ten days. The study took place during the day, but there were nocturnal collections that stayed in the environment overnight and used white cloth to attract the insects. Triatominae samples were sought in trees, stones and their attachments.

Natural infection of triatomines by trypanosomatid forms was analyzed in feces obtained by abdominal compression. The natural infection index was obtained from the ratio between the number of infected triatomines and the number of examined triatomines. ${ }^{12}$
In order to isolate and confirm the parasite, samples tested positive for trypanosomatids were diluted with $0.9 \%$ saline and examined between slide and coverslip under optical microscopy. Then $0.3 \mathrm{~mL}$ was intraperitoneally injected into Swiss mice aged 23 and 35 days, and another $0.3 \mathrm{~mL}$ was inoculated in Liver Infusion Tryptose medium. Around 15 days following the inoculation, the peripheral blood of the mice was checked for flagellate forms and the regular growth of the parasite in LIT medium was verified. ${ }^{17}$ The 28 strains of $T$. cruzi are

Table 2. Natural ecotopes investigated in cities in the states of Bahia and Rio Grande do Sul, indicating Triatominae foci, 2002-2009.

\begin{tabular}{|c|c|c|c|c|}
\hline Species & Locality & Triatominae examined & Positive & $\%$ \\
\hline T. circummaculata & Caçapava do Sul, RS & 8 & 0 & 0 \\
\hline T. circummaculata & Lavras, RS & 3 & 0 & 0 \\
\hline T. sherlocki & Santo Inácio, BA & 26 & 0 & 0 \\
\hline T. pseudomaculata & Santo Inácio, BA & 1 & 0 & 0 \\
\hline T. pseudomaculata & Macaúbas, BA & 1 & 0 & 0 \\
\hline P. geniculatus & Macaúbas, BA & 1 & 0 & 0 \\
\hline T. sordida & Santo Inácio, BA & 1 & 0 & 0 \\
\hline T. sordida & Macaúbas, BA & 324 & 0 & 0 \\
\hline T. rubrovaria & Lavras, RS & 36 & 0 & 0 \\
\hline T. rubrovaria & Quaraí, RS & 53 & 2 & 3.7 \\
\hline T. lenti & Macaúbas, BA & 90 & 4 & 4.4 \\
\hline T. sordida & Macaúbas, BA & 100 & 6 & 6.1 \\
\hline T. melanocephala & Poções, Jequié, Bom Jesus da Serra, BA & 11 & 1 & 9.0 \\
\hline T. sordida & Santo Inácio, BA & 35 & 12 & 34.0 \\
\hline T. rubrovaria & Santana do Livramento, RS & 5 & 3 & 60.0 \\
\hline T. rubrovaria & Quaraí, RS & 21 & 15 & 71.0 \\
\hline T. lenti & Macaúbas, BA & 4 & 3 & 75.0 \\
\hline Total & - & 720 & 46 & 6.4 \\
\hline
\end{tabular}


in study by molecular techniques and biological assays such as cellular infection, growth kinetics in LIT medium and parasitemia curve in BALB/c mice. In the present work these data were not included because some trials are ongoing in the laboratory and will be published later.

All the procedures were reported to and approved by the Ethical Committee for Animal Experimentation of the Universidade Estadual Paulista "Júlio de Mesquita Filho”-Araraquara (Protocol 13/2012).

\section{RESULTS}

In Rio Grande do Sul, two triatomine species were collected: Triatoma circummaculata, which tested negative for T. cruzi in all 11 samples taken, and Triatoma rubrovaria, with 20 specimens (of the 115) testing positive for T. cruzi (Table 2, Figure).

In Bahia, six species were collected: Panstrongylus geniculatus, Triatoma melanocephala, Triatoma lenti, Triatoma pseudomaculata, Triatoma sherlocki and Triatoma sordida, summing up 594 captured specimens, $4.4 \%$ of them naturally infected (Table 2, Figure).

From the examined specimens (720) a total of 28 T. cruzi strains were isolated: one from the vector T. melanocephala, one from T. lenti, 16 from T. rubrovaria, and 10 from $T$. sordida with the $\mathrm{SIGR}_{3}$ strain was isolated in 2006 by cat xenodiagnosis in a peridomestic area of Santo Inácio, Bahia. ${ }^{17}$ (Table 3).

Triatoma melanocephala specimens were collected in the cities of Jequié, Poções and Bom Jesus da Serra, BA, and only one specimen provided a T. cruzi strain, named "Tm".

\section{DISCUSSION}

Epidemiological studies on Chagas disease and vector capture have been conducted in both endemic and non-endemic areas. ${ }^{1,7,8,18}$ In areas where vector-borne transmission was controlled by measures against the main vector of the disease, namely Triatoma infestans, invasion and colonization by secondary vectors can be observed, and they were sometimes captured inside the houses. Species like T. sordida and P. megistus in Sao Paulo (Southeastern Brazil), T. rubrovaria in Rio Grande do Sul, ${ }^{2}$ Southtern Brasil, and T. brasiliensis in Northeastern Brazil ${ }^{2}$ are examples of that situation.

Originally, sylvatic specimens of triatomine can adapt to peridomestic and domestic environments occupying the ecological niche of primary species. In this sense, the gathering of the T. sherlocki in sylvatic and domestic environment may indicate that sylvatic populations have invaded and colonized localities, thus the importance of entomological surveys. The presence of triatomines
Table 3. Strains of Trypanosoma cruzi isolated and maintained in laboratory.

\begin{tabular}{|c|c|c|}
\hline Species & Strain & Year of collection \\
\hline \multirow[t]{16}{*}{ T. rubrovaria } & QG1 & 2002 \\
\hline & QG2 & 2002 \\
\hline & נ & 2003 \\
\hline & JIII & 2003 \\
\hline & QBI & 2003 \\
\hline & QMM1 & 2008 \\
\hline & QMM2 & 2008 \\
\hline & QMM3 & 2008 \\
\hline & QMM4 & 2008 \\
\hline & QMM5 & 2008 \\
\hline & QMM6 & 2008 \\
\hline & QMM7 & 2008 \\
\hline & QMM9 & 2008 \\
\hline & QMM10 & 2008 \\
\hline & QMM11 & 2008 \\
\hline & QMM12 & 2008 \\
\hline \multirow[t]{10}{*}{ T. sordida } & SI1 & 2003 \\
\hline & $\mathrm{SI} 2$ & 2003 \\
\hline & $\mathrm{SI} 3$ & 2003 \\
\hline & SI5 & 2003 \\
\hline & SI7 & 2003 \\
\hline & SI8 & 2003 \\
\hline & SI9 & 2003 \\
\hline & SI11 & 2003 \\
\hline & $\mathrm{SIGR}^{\mathrm{a}}$ & 2006 \\
\hline & SIGR5 ${ }^{\mathrm{a}}$ & 2006 \\
\hline T. lenti & T. lenti & 2008 \\
\hline T. melanocephala & $\mathrm{Tm}$ & 2009 \\
\hline Total & 28 & - \\
\hline
\end{tabular}

inside houses represents a risk of vector-borne transmission of Chagas disease to humans. ${ }^{3}$ In Brazil, there are 52 species, but five of them - Panstrongylus megistus, Triatoma brasiliensis, T. infestans, T. pseudomaculata and $T$. sordida - have considerable epidemiological importance. ${ }^{6}$ Triatoma sordida is one of the most captured species in Brazil and is regarded as mostly peridomiciliary, whereupon it can be found naturally infected by T. cruzi. Therefore, that species has an important role in the maintenance and transmission of Chagas disease. ${ }^{3}$

In order to have a better understanding of the response of that triatomine to the control activities, research was carried out in 12 rural localities in the city of Porteirinha, MG, Southeastern Brazil. ${ }^{9}$ A total of 772 specimens of $T$. sordida were captured, of which $3.6 \%$ were infected by $T$. cruzi. Of the 406 domiciliary units researched, 34.9\% were 
infested. Of the 695 peridomiciliary ecotopes, $27.6 \%$ had T. sordida. Triatoma rubrovaria is distributed in a wide area comprehending Argentina, Uruguay and Southern Brazil $^{13,18}$ and it lives in holes and cracks in rocky places in fields. It can be captured in domiciles in rural areas next to sylvatic ecotopes, which explains its epidemiological importance. ${ }^{18}$ Almeida et al $^{1}$ (2000) reported the presence of that species in a domiciliary environment, confirming its ability to invade and colonize houses. ${ }^{2}$

Trypanosoma cruzi has genetically different strains for which more than 100 mammalian species can serve as reservoirs. ${ }^{7}$ Geographic distribution in the Americas depends on the interaction of the parasite with the vector, and natural infection can only take place when the trypanosomatid-triatomine system is balanced. ${ }^{11}$ So far, there are six groups of parasite - Discrete Typing Units (DTU): TcI, TcII, TcIII, TcIV, TcV and TcVI ${ }^{14}$ and biological differences among strains are pointed out by researchers. ${ }^{5,16,21}$ Martins et $\mathrm{al}^{15}$ (2008) performed the molecular and biological characterization of five isolates obtained from T. rubrovaria collected in Rio Grande do Sul wherein $1.6 \%$ of the collected specimens were positive for $T$. cruzi. Rimoldi et al ${ }^{17}$ (2012) showed the biological diversity of strains isolated from $T$. sordida and a domestic cat in Santo Inácio, Bahia.

Freitas et $\mathrm{al}^{10}(2005)$ collected 921 specimens of $T$. pseudomaculata in cities in the state of Ceará, Northeastern Brazil. Even though they tested negative for T. cruzi, the presence of that vector in that region is clear. In 1980 Sherlock \& Guitton ${ }^{19}$ (1980) collected 12 samples of $T$. lenti in Bahia and all of them were positive for T. cruzi. The fact that the specimens tested positive shows the importance of that vector in the transmission of Chagas disease in the state. Few studies related to T. lenti and T. melanocephala are found in the literature and in this sense this work can contribute.

Chagas disease can be controlled by interruption of the transmission mechanisms, improvement of dwellings and adjacent areas, education, basic sanitation for exposed populations, and treatment. To make control successful, it is essential to completely prevent contact between triatomines and humans in areas surrounding habitations, which could be achieved by the use of residual insecticides, improvement of dwellings, and repair of crevices in walls using plaster, preventing triatomines from having a place to hide. ${ }^{6}$

In view of the 28 strains of $T$. cruzi collected from species regarded as "secondary", such as T. sordida and T. rubrovaria, it is necessary to continue entomological surveillance and health education actions in order to minimize the chances of triatomines colonizing domestic and peridomestic areas in cities in the states of Bahia and Rio Grande do Sul. This study continues with biological, morphological and molecular approaches under development.

\section{ACKNOWLEDGMENTS}

To Julio César Rente Ferreira Filho, who collected Triatoma lenti, Eliane Góes Nascimento, from the Health Department of the State of Bahia/SESAB - Entomology Division, for sending specimens of Triatoma melanocephala. 


\section{REFERENCES}

1. Almeida CE, Vinhaes MC, Almeida JR, Silveira AC, Costa J. Monitoring the domiciliary and peridomiciliary invasion process of Triatoma rubrovaria in the State of Rio Grande do Sul, Brazil. Mem Inst Oswaldo Cruz. 2000;95(6):761-8. DOI:10.1590/S0074-02762000000600003

2. Almeida CE, Pacheco RS, Haag K, Dupas S, Dotson EM, Costa J. Inferring from the Cyt B gene the Triatoma brasiliensis Neiva, 1911 (Hemiptera: Reduviidae: Triatominae) genetic structure and domiciliary infestation in the Sstate of Paraíba, Brazil. Am / Trop Med Hyg. 2008;78(5):791-802.

3. Araújo CAC, Waniek PJ, Jansen AM. An overview of Chagas disease and the role of triatomines on its distribution in Brazil. Vector Borne Zoonotic Dis. 2009;9(3):227-34. DOI:10.1089/vbz.2008.0185

4. Bedin C, Mello F, Wilhelms TS, Torres MA, Estima C, Ferreira CF, et al. Vigilância ambiental: doença de Chagas no Rio Grande do Sul. Bol Epidemiol CEVS/RS. 2009;11(3):1- 8

5. Chagas C. Nova tripanozomiaze humana: estudos sobre a morfolojia e o ciclo evolutivo do Schizotrypanum cruzi n.gen. n.sp., ajente etiolojico de nova entidade morbida do homem. Mem Inst Oswaldo Cruz. 1909;1(2):159-218. DOI:10.1590/S0074-02761909000200008

6. Coura JR, Dias JCP. Epidemiology, control and surveillance of Chagas disease: 100 years after its discovery. Mem Inst Oswaldo Cruz. 2009;104(1):31-40. DOI:10.1590/S0074-02762009000900006

7. Coura JR, Viñas PA. Chagas disease: a new worldwide challenge. Nature. 2010;465(7301)S6-7. DOI:10.1038/nature09221

8. Dias JCP, Machado EMM, Fernandes AL, Vinhaes MC. Esboço geral e perspectivas da doença de Chagas no Nordeste do Brasil. Cad Saude Publica. 2000;16(Supl 2):S13-34. DOI:10.1590/S0102-311X2000000800003

9. Diotaiuti L, Azeredo BVM, Busek SCU, Fernandes AJ. Controle do Triatoma sordida no peridomicílio rural do município de Porteirinha, Minas Gerais, Brasil. Rev Panam Salud Publica. 1998;3(1):21-5. DOI:10.1590/S1020-49891998000100004

10. Freitas SPC, Lorosa ES, Rodrigues DCS, Freitas ALC, Gonçalves TCM. Fontes alimentares de Triatoma pseudomaculata no Estado do Ceará, Brasil. Rev Saude Publica. 2005;39(1):27-32. DOI:10.1590/S0034-89102005000100004

11. Garcia ES, Ratcliffe NA, Whitten MM, Gonzales MS Azambuja P. Exploring the role of insect host factors in the dynamics of Trypanosoma cruzi - Rhodnius prolixus interactions. J Insect Physiol. 2007;53(1):11-21. DOI:10.1016/j.jinsphys.2006.10.006
12. Gurgel-Gonçalves R, Pereira FCA, Lima IP, Cavalcante RR. Distribuição geográfica, infestação domiciliar e infecção natural de triatomíneos (Hemiptera: Reduviidae) no Estado do Piauí, Brasil, 2008. Rev PanAmaz Saude. 2010;1(4):57-64.

13. Lent $\mathrm{H}$, Wygodzinsky PW. Revision of the Triatominae (Hemiptera, Reduviidae) and their significance as vectors of Chagas' Disease. Bull Am Mus Nat History. 1979;163(article 3):123-529.

14. Lewis MD, Jonathan MA, Carrasco HJ, Llewellyn MS, Miles MA. Genotyping of Trypanosoma cruzi: systematic selection of assays allowing rapid and accurate discrimination of all know lineages. Am J Trop Med Hyg. 2009;81(6):1041-9. DOI:10.4269/ajtmh.2009.09-0305

15. Martins LPA, Marcili A, Castanho REP, Therezo ALS, Oliveira JCP, Suzuki RB, et al. Rural Triatoma rubrovaria from Southern Brazil harbors Trypanosoma cruzi of Lineage Ilc. Am J Trop Med Hyg. 2008;79(3):427-34.

16. Pena DA, Eger I, Nogueira L, Heck N, Menin A, Báfica A, et al. Selection of Tcll Trypanosoma cruzi population following macrophage infection. J Infect Dis. 2011;204(3):478-86. DOI:10.1093/infdis/jir292

17. Rimoldi A, Alves RT, Ambrósio DL, Fernandes MZT, Martinez I, Araújo RF, et al. Morphological, biological and molecular characterization of three strains of Trypanosoma cruzi Chagas, 1909 (Kinetoplastida, Trypanosomatidae) isolated from Triatoma sordida (Stal) 1859 (Hemiptera, Reduviidae) and a domestic cat. Parasitology. 2012;139(1):37-44. DOI:10.1017/S0031182011001697

18. Rosa JA, Barata JMS, Santos JLF, Cilense M. Morfologia de ovos de Triatoma circummaculata e Triatoma rubrovaria (Hemiptera, Reduviidae). Rev Saude Publica. 2000;34(5):538-42. DOI:10.1590/S0034-89102000000500015

19. Sherlock IA, Guitton N. Fauna Triatominae do Estado da Bahia Brasil III: notas sobre ecótopos silvestres e o gênero Psammolestes.MemInstOswaldoCruz.1974;72(1-2):91-101. DOI:10.1590/S0074-02761974000100011

20. Silveira AC, Dias JCP. O controle da transmissão vetorial. Rev Soc Bras Med Trop. 2011;44(Suppl 2):52-63. DOI:10.1590/S0037-86822011000800009

21. Zingales B, Andrade SG, Briones MRS, Campbell DA, Chiari E, Fernandes $\mathrm{O}$, et al. A new consensus for Trypanosoma cruzi intraspecific nomenclature: second revision meeting recommends $\mathrm{TCl}$ to $\mathrm{TcVI}$. Mem Inst Oswaldo Cruz. 2009;104(7):1051-4. DOI:10.1590/S0074-02762009000700021

22. Zingales B, Miles MA, Campbell DA, Tibayrenc M, Macedo AM, Teixeira MMG, et al. The revised Trypanosoma cruzi subspecific nomenclature: rationale, epidemiological relevance and research applications. Infect Genet Evol. 2012;12(2):240-53. DOI:10.1016/j.meegid.2011.12.009

This study was supported by the Programa de Apoio ao Desenvolvimento Cientifico (PADC) of the Faculdade de Ciências Farmacêuticas of the Campus de Araraquara of the Universidade Estadual Paulista "Júlio de Mesquita Filho" (UNESP) (Process 2013/26-III), by the Fundação para o Desenvolvimento da UNESP (Fundunesp) of the Faculdade de Ciências Farmacêuticas of the Campus de Araraquara of the UNESP (Process 00066/06), by the Fundação de Amparo à Pesquisa do Estado de São Paulo (FAPESP) (Process 13/08826-5), and by the Coordenação de Aperfeiçoamento de Pessoal de Nível Superior (CAPES - Process 23038.005285/2011-12).

The authors declare that there is no conflict of interest. 


\section{HIGHLIGHTS}

The transmission of Chagas disease by vectors was considered to be under control in certain regions of Brazil. This work shows that some species of triatominae, such as Panstrongylus geniculatus, Triatoma melanocephala, Triatoma lenti, Triatoma pseudomaculata, Triatoma sherlocki, Triatoma sordida, Triatoma circummaculata and Triatoma rubrovaria can be found in municipalities in the states of Bahia and Rio Grande do Sul. Some of the specimens studied tested positive for Trypanosoma cruzi, calling for extra attention to be paid, as during the capture period (2002-2009) infected vertebrate reservoirs were found in household, peridomestic and wild environments.

Of the specimens examined, T. cruzi was isolated in 28 triatominae from four different species: T. melanocephala, T. lenti, T. rubrovaria and T. sordida, presenting a natural infection rate of $6.4 \%$.

Isolating strains of $T$. cruzi from the triatominae captured in the intra and peridomestic environments reflects the potential risk of Chagas disease transmission in the municipalities studied. This work contributes to increasing knowledge of the distribution of triatominae, as well as encouraging effective control of Chagas infection, as it presents data on natural infection and the distribution of vectors in the states of Bahia and Rio Grande do Sul.

Professor Rita de Cássia Barradas Barata Scientific Editor 